\title{
Characterization of the $\beta$ Phase Decomposition in Ti-5Al-5Mo-5V-3Cr at Slow Heating Rates
}

\author{
Quentin Contrepois, Marc Carton, Jacqueline Lecomte-Beckers \\ Aerospace and Mechanical Engineering Department, Metallic Materials Science Unit, \\ University of Liège, Chemin des chevreuils 1, Belgium \\ E-mail: jacqueline.lecomte@ulg.ac.be \\ Received July 12, 2011; revised August 22, 2011; accepted September 8, 2011
}

\begin{abstract}
The influence of slow heating rates: $2,5,10$ and $30^{\circ} \mathrm{C} / \mathrm{min}\left(0.033,0.083,0.166\right.$ and $\left.0.50^{\circ} \mathrm{C} / \mathrm{s}\right)$ on the $\beta$ phase decomposition of Ti-5Al-5Mo-5V-3Cr (Ti-5553) during continuous heating were characterized by differential scanning calorimetry (DSC) analysis, light microscopy, scanning electron microscopy, X-ray diffraction and hardness testing. Starting microstructure was the $\beta$ phase obtained by heating the Ti-5553 above the T $\beta$ temperature and a water quench. Results show that heating rate has a significant impact on the precipitation mechanisms and on the $\beta \rightarrow \alpha$ transformation in this range of heating rates. The main formation of $\alpha$ precipitates occurs between 500 and $600^{\circ} \mathrm{C}$ at all heating rates tested. A heating at $2^{\circ} \mathrm{C} /$ min produces very fine and homogeneously distributed $\alpha$ plate precipitates which have nucleated on the nanometer size $\omega_{\text {iso }}$ precipitates. The $\omega_{\text {iso }}$ precipitates between 350 and $400^{\circ} \mathrm{C}$. At higher heating rates 10,15 or $30^{\circ} \mathrm{C} / \mathrm{min}$, the amount of precipitation of $\omega_{\text {iso }}$ is lower so an additional formation of nanometer size precipitates occurs between 450 and $500^{\circ} \mathrm{C}$. It is supposed that both precipitates act as nucleation sites for $\alpha$ phase precipitation. The resultant microstructure consists in a fine intragranular distribution of $\alpha$ precipitates and a coarser precipitation of $\alpha$ at the grain boundaries. It is shown that the precipitation of $\omega_{\text {iso }}$ phase retards or prevents the precipitation of nanometer size precipitates occurring between 450 and $500^{\circ} \mathrm{C}$. This cannot be generalized to all the $\beta$-metastable titanium alloys since Ti-LCB does not exhibit the same heating rate dependence on DSC curves.
\end{abstract}

Keywords: $\beta$ Metastable Titanium Alloy, $\omega$ Phase, Precipitation, Microstructure, DSC

\section{Introduction}

Ti-5Al-5Mo-5V-3Cr, or Ti-5553, is a high-strength $\beta$ metastable (or $\beta$ ) titanium alloy comparable to the old Russian $\beta$-metastable alloy VT-22. Ti-5553 was primarily designed for high-strength forging applications on account of improved properties and deep hardenability over large thickness; moreover, it exhibits less sensitivity to forming variables compared to Ti-10Al-2Fe-3Al and thus offers processing benefits [1]. A wide variety of strength, ductility and fracture toughness values can be achieved depending on thermomechanical processing and heat treatment with these types of alloys [2,3] making Ti5553 potentially useful for various thick aerospace applications where weight reduction must be achieved (for example in the low-pressure compressor or the landing gear). Ti-LCB (Low Cost Beta Titanium) is another $\beta$ metastable alloy used in mechanical applications; it is very attractive since the more costly $\beta$ stabilizing ele- ments are replaced.

The mechanical properties of titanium alloys are controlled by their microstructure, in particular the size, shape and distribution of the $\alpha$ phase in the $\beta$-matrix [3]. Therefore, a good understanding of the alloy behavior during thermomechanical treatments is closely related to the knowledge of phase transformations or precipitations and the effect of temperature on the microstructure evolution.

This paper investigates Ti-5553 and to a lesser extent Ti-LCB solid $\beta$ phase decomposition and precipitations using differential scanning calorimetry (DSC) during various slow heating rates. Phases are revealed by X-ray diffraction (XRD) analysis in addition to light microscopy (LM), scanning electron microscopy (SEM) and hardness testing. The starting microstructure is a fully $\beta$-matrix free of $\alpha$ phase, resulting from a heating above the T $\beta$ transus temperature and a water quench (WQ).

The aim of this study is to show the particular $\beta$ phase 
decomposition of the Ti-5553 alloy during slow heating rates in the range of $2-30^{\circ} \mathrm{C} / \mathrm{min}$ and to put in relief the importance of heating rate when studying these types of alloys. Ivasishin et al. [4,5] have shown the importance of the heating rate on various $\mathrm{Ti}$ alloys including the predecessor of Ti-5553, VT-22, and showed that different precipitation mechanisms occurred by varying the heating rate until the ageing temperature. At slow heating rates $\left(15^{\circ} \mathrm{C} / \mathrm{min}\right.$ or $\left.0.25^{\circ} \mathrm{C} / \mathrm{s}\right)$, they observed a fine, plate-like $\alpha$ precipitation and at very high heating rates $\left(1200^{\circ} \mathrm{C} / \mathrm{min}\right.$ or $\left.20^{\circ} \mathrm{C} / \mathrm{s}\right)$ a coarse plate-like $\alpha$ microstructure. They attributed this difference to the precipitation of the $\omega$ isothermal phase $\left(\omega_{\text {iso }}\right)$ which acts as nucleation sites for the $\alpha$ precipitates in addition to the classical microstructural items such as grain boundaries, dislocations or precipitates. The main difference with our study is the difference in heating rates analysed: 15 and $1200^{\circ} \mathrm{C} / \mathrm{min}$ in the Ivasishin studies and 2, 5, 15 and $30^{\circ} \mathrm{C} / \mathrm{min}$ for ours, plus the studied alloy Ti-5553 which is slightly different from VT-22. In addition, in a recent study, Wain et al. [6] characterized a refinement of the $\alpha$ precipitation in Ti-5553 by using either a low-temperature pre-ageing at $250^{\circ} \mathrm{C}$ or a sufficiently slow heating rate up to the final ageing temperature when starting from a $\beta$ phase microstructure and according to these authors, the mechanism responsible for such a refinement is also an enhanced $\alpha$ nucleation on fine $\omega_{\text {iso }}$ precipitates. Two forms of $\omega$ phase are differentiated: athermal $\omega\left(\omega_{\text {ath }}\right)$ which appears without diffusion during cooling from the high temperature $\beta$ phase field and isothermal $\omega\left(\omega_{\text {iso }}\right)$ which precipitates during low temperature ageing.

Influence of heating rate on $\beta$ phase decomposition was also studied in the $\beta$-metastable titanium alloys Ti-B19 (Ti-3Al-5Mo-5V-4Cr-2Zr) [7] by electrical resistivity measurements and Ti17 (Ti-5Al-4Mo-4Cr-2Zr-2Sn) [8] by in situ high energy XRD. It was shown in Ti-B19 [7] that $\omega_{\text {iso }}$ precipitates between 280 and $350^{\circ} \mathrm{C}$ during a $6^{\circ} \mathrm{C} / \mathrm{min}$ heating but not during 60 and $600^{\circ} \mathrm{C} / \mathrm{min}$ heating. Moreover the precipitation of the orthorhombic $\alpha$ " phase was evidence between 350 and $450^{\circ} \mathrm{C}$ at $6^{\circ} \mathrm{C} / \mathrm{min}$. Similarly, two different $\beta$ phase decompositions are evidence in Ti17 [8]: at low heating rate $30^{\circ} \mathrm{C} / \mathrm{min}$ :

$\beta\left(250^{\circ} \mathrm{C}\right) \rightarrow \omega+\beta\left(393^{\circ} \mathrm{C}\right) \rightarrow \alpha " \beta\left(490^{\circ} \mathrm{C}\right) \rightarrow \alpha " \alpha$ $+\beta\left(590^{\circ} \mathrm{C}\right) \rightarrow \beta+\alpha\left(633^{\circ} \mathrm{C}\right)$

and at high heating rate $300^{\circ} \mathrm{C} / \mathrm{min}$ :

$\beta\left(300^{\circ} \mathrm{C}\right) \rightarrow \alpha "+\beta\left(528^{\circ} \mathrm{C}\right) \rightarrow \alpha "+\alpha+\beta\left(604^{\circ} \mathrm{C}\right) \rightarrow \alpha$ $+\beta\left(632^{\circ} \mathrm{C}\right)$

(Temperatures in brackets correspond to the temperatures of analyses).

It is then shown that the precipitation of $\omega_{\text {iso }}$ is suppressed at $300^{\circ} \mathrm{C} / \mathrm{min}$ heating rate.

Presence of $\omega$ precipitates in Ti-5553 has already been reported in detail in previous papers $[9,10,11,12,13]$. Jo- nes et al. [13] for example clearly showed, using in situ high energy XRD in a synchrotron that the $\omega_{\text {ath }}$ phase appears during rapid cooling from above the $\beta$ transus temperature in Ti-5553 as much as $20 \%$ in volume. The role played by the $\omega$ phase in the $\alpha$ precipitation in this type of alloy is of interest and the possible mechanisms have been discussed previously $[9,10,11,12]$.

Ohmori et al. [9] have discussed the role of $\omega$ precipitates on the nucleation of the HCP $\alpha$ and orthorhombic $\alpha$ " phases in a $\beta$-metastable titanium alloy (Ti-9.87V$1.78 \mathrm{Fe}-3.20 \mathrm{Al})$. Thanks to transmission electron microscopy (TEM) analysis they showed that $\alpha$ laths nucleate at the $\omega / \beta$ interface and grow into both the $\beta$ matrix and the $\omega$ particles at temperatures above $350^{\circ} \mathrm{C}$. Nag et al. [12] investigated the role of $\omega$ precipitates on the intragranular nucleation of $\alpha$ precipitates in Ti-5553, it is thought to arise from two possible causes: 1- nucleation near the $\omega / \beta$ interface by local rejection of Al which is an $\omega$ destabilizer and a strong $\alpha$ stabilizer [14]; 2-displacive transformation within the core of the $\omega$ precipitates, leading to the formation of $\alpha$ platelets [10]. The importance of $\omega / \beta$ misfit in the $\alpha$ nucleation mechanisms is reminded, when there is a large misfit between the $\omega$ and $\beta$ phases, $\alpha$ precipitates nucleate on ledges and misfit dislocations at $\omega / \beta$ interfaces. But Ti-5553 is thought to exhibit a low $\omega / \beta$ misfit so the role of $\omega$ on the nucleation of $\alpha$ precipitates is not clearly understood. Their detailed study leads to the conclusion that the $\beta$ to $\alpha$ transformation and a compositional partitioning of alloying elements occur in sequential steps, resulting in a mixed-mode displacive-diffusional transformation. Indeed, their experimental results indicate that a thermally activated diffusive process leads to the initial partitioning of alloying elements during coarsening of the $\omega$ precipitates, leading to the creation of favorable sites, marginally enriched in $\mathrm{Al}$, for the nucleation of the $\alpha$ precipitates. Subsequently, these precipitates nucleate by a primarily displacive process, with a composition marginally enriched in $\mathrm{Al}$ as compared with the parent $\beta$ matrix. These precipitates then grow via a coupled displacivediffusional process with the diffusional partitioning of the alloying elements being rate-controlling. It is very interesting to note that: - after an annealing at $350^{\circ} \mathrm{C}(2 \mathrm{~h})$ they detect a coarsening of $\omega$ precipitates and nucleation of $\alpha$ precipitates, - after an annealing at $400^{\circ} \mathrm{C}(2 \mathrm{~h})$ there is less $\omega$ phase than at $350^{\circ} \mathrm{C}$ but more $\alpha$ precipitates, and finally after an annealing at $600^{\circ} \mathrm{C}$ they observe a growth and coarsening of $\alpha$ precipitates. They unfortunately do not mention any heating rate, which leads us to think that the samples were introduced into the furnace preheated to the desired temperature. However, we will see in our study that the thermal route have a high impact on the precipitation mechanisms, and especially the heating rate. 
This overview shows that the presence of $\omega$ precipitates is of great importance for $\alpha$ nucleation and that the heating rate can have a strong impact on the $\omega$ phase formation so that we propose to analyze the role played by heating rate during the $\beta$ phase decomposition of a $\beta$-metastable alloy.

\section{Materials and Experimental Procedures}

Ti-5553 was provided by Timet Ugine (France), it was produced in the form of a forged billet of $200 \mathrm{~mm}$ in diameter, the chemical composition of Ti-5553 is presented in Table 1. The conventional microstructure delivered by the producer is an $\alpha+\beta$ bimodal microstructure (see Figure 1-(a)), consisting of large globular primary $\alpha$ precipitates and smaller secondary $\alpha$ platelets in a $\beta$ - matrix. This microstructure is achieved by a two-step ageing heat treatment at $820^{\circ} \mathrm{C}$ for $2 \mathrm{~h}$ (i.e. below the $\mathrm{T} \beta$ transus) and at $630^{\circ} \mathrm{C}$ for $8 \mathrm{~h}$. This state is called "bimodal". Ti5553 has been solution heat treated at a super-transus temperature of $865^{\circ} \mathrm{C}$ (i.e. above the $\mathrm{T} \beta$ transus) over 30 min and water quenched in order to get a fully $\beta$-metastable matrix free of $\alpha$ phase (but the presence of $\omega_{\text {ath }}$ is expected). This state is termed the " $\beta$-solutionized" state (see Figure 1-(b)). Similar solution heat treatment was conducted with one other $\beta$-metastable titanium alloy: the Ti-LCB at $810^{\circ} \mathrm{C}$ for $30 \mathrm{~min}$ and water quenched, in order to compare the chemical composition effect. The Ti-5553 $\beta$-solutionized samples were heated at two different rates: $2^{\circ} \mathrm{C}$ and $30^{\circ} \mathrm{C} / \mathrm{min}$ using a resistance heating furnace at four different temperatures: 300, 400, 500 and $600^{\circ} \mathrm{C}$ and then water quenched.

Differential scanning calorimetry (DSC) is a thermoanalytical technique in which the difference in the amount of heat required to increase the temperature of a sample and a reference is measured as a function of temperature. When the sample undergoes an endothermic or an exothermic physical transformation, heat flux is measured and compared to the reference which must have a well-defined heat capacity over the range of temperatures scanned. The difference of heat flux enables the detection of transformations such as solid phase transformations. Usually, the temperature program for a DSC analysis is designed in such a way that the sample temperature increases linearly as a function of time. DSC analyses were performed on a Netzsch DSC 404C device at four different heating rates: $2,5,10$ and $15^{\circ} \mathrm{C} / \mathrm{min}$, on Ti-5553 and Ti-LCB samples in the initial $\beta$-solutionized states (respectively $865^{\circ} \mathrm{C}$ and $810^{\circ} \mathrm{C}$ for $30 \mathrm{~min}$ then water-quenched). The heating rates $15^{\circ} \mathrm{C} / \mathrm{min}$ should have been chosen instead of $30^{\circ} \mathrm{C} / \mathrm{min}$ for the heat treatment of samples in the resistance heating furnace, but this furnace wasn't able to correctly heat at a constant rate of
Table 1. Chemical composition of Ti-5553 and Ti-LCB alloys.

\begin{tabular}{cccccc}
\hline (wt\%) & Al & Mo & V & Cr & Fe \\
\hline Ti-5553 & 5 & 5 & 5 & 3 & 0.3 \\
Ti-LCB & 1.5 & 6.8 & & & 4.5 \\
\hline
\end{tabular}

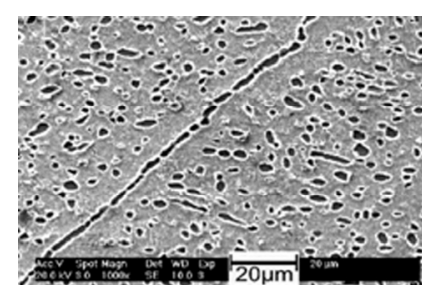

(a)

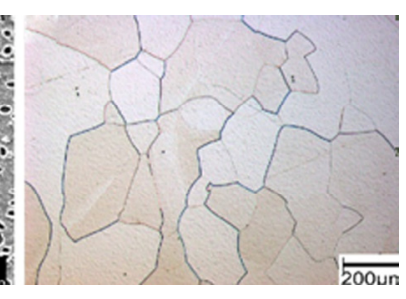

(b)
Figure 1. Microstructures of Ti-5553: (a). SEM micrograph in as-received bimodal state $\left(820^{\circ} \mathrm{C}-2 \mathrm{~h} / 630^{\circ} \mathrm{C}-8 \mathrm{~h}\right)$ consisting of globular primary alpha in fine lamellar $\alpha+\beta$ matrix; (b). LM micrograph of $\beta$-solutionized Ti-5553 (865 ${ }^{\circ} \mathrm{C}$ $30 \mathrm{~min} / \mathrm{WQ})$.

$15^{\circ} \mathrm{C} / \mathrm{min}$. We assume that $15^{\circ} \mathrm{C} / \mathrm{min}$ and $30^{\circ} \mathrm{C} / \mathrm{min}$ lead to comparable microstructures in this paper.

XRD analyses were performed on a Siemens D-5000 $\mathrm{X}$-ray diffractometer using the $\mathrm{Cu}-\mathrm{K}_{\alpha}$ ray of wavelength $1.5406 \AA$. Samples were mechanically polished using the following steps: $\mathrm{SiC}$ papers (320 to 1200), diamond paste (9 and $3 \mu \mathrm{m}$ ), colloidal silica suspension (OPS with $\mathrm{H}_{2} \mathrm{O}_{2}$ ). The microstructures were revealed by chemical etching with 5\% $\mathrm{HNO}-5 \% \mathrm{HF}$ in a water solution (known as Kroll etchant).

Electronic SEM micrographs were carried out with an XL30 ESEM-FEG. Hardness was measured as Vickers hardness with a $10 \mathrm{~kg}$ load on an EMCO-TEST device.

\section{Results}

\subsection{DSC Curves of Ti-5553 in $\beta$-Solutionized State $\left(865^{\circ} \mathrm{C}-30 \mathrm{~min} / \mathrm{WQ}\right)$}

Samples of $\beta$-solutionized Ti-5553 were analyzed by DSC. The thermal cycles consisted of heating at constant rates from room temperature to $930^{\circ} \mathrm{C}$ to achieve a final temperature above the $\mathrm{T} \beta$ transus. In order to characterize a possible kinetic effect on the phase transformations, four different heating rates were tested: 2, 5, 10 and $15^{\circ} \mathrm{C} / \mathrm{min}$. The DSC curves obtained during heating are shown in Figure 2. These curves are complex and the exothermic or endothermic nature of the transformation peaks is not easy to identify. The particular difficulty in DSC analysis is to correctly define a baseline which enables detection of the heat flux characteristic of phase we can determine three different "steps" or "areas", called A, 

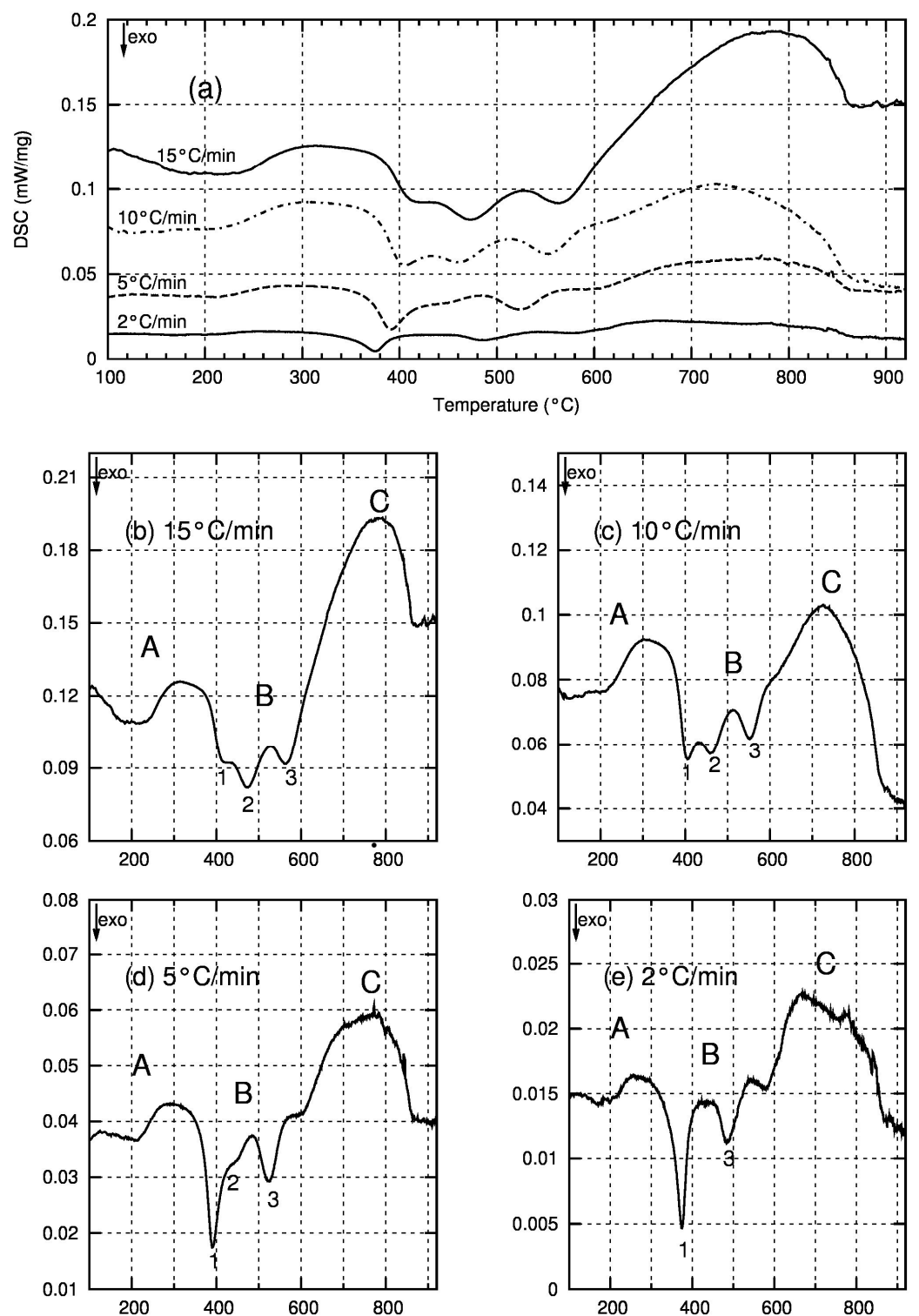

Figure 2. DSC curves of $\beta$-solutionized Ti-5553 $\left(865^{\circ} \mathrm{C}-30 \mathrm{~min} / \mathrm{WQ}\right)$ at: (a). the four heating rates; (b). $15^{\circ} \mathrm{C} / \mathrm{min},(\mathrm{c})$. $10^{\circ} \mathrm{C} / \mathrm{min}$; (d). $5^{\circ} \mathrm{C} / \mathrm{min} ;$ (e). $2^{\circ} \mathrm{C} / \mathrm{min}$.

$\mathrm{B}$ and $\mathrm{C}$ in Figure 2, for all the heating rates. transformations. If we consider a baseline approximately horizontal at a DSC value close to the start of the curves, The first area A is not clear; it can either be an exothermic reaction zone located at about $200^{\circ} \mathrm{C}$ or an endothermic reaction ranging from about $220^{\circ} \mathrm{C}$ to $350^{\circ} \mathrm{C}$, we think this is an endothermic peak. The second area $\mathrm{B}$ is a series of exothermic peaks ranging from about $350^{\circ} \mathrm{C}$ to $575^{\circ} \mathrm{C}$ (labeled 1 to 3 on the curves) and the third area $\mathrm{C}$ is an endothermic peak ranging from about $600^{\circ} \mathrm{C}$ to $860^{\circ} \mathrm{C}$. As the $\mathrm{T} \beta$ transus is known to be near $865^{\circ} \mathrm{C}$, we assume that the endothermic reaction (area $\mathrm{C}$ ) between about $650^{\circ} \mathrm{C}$ to $860^{\circ} \mathrm{C}$ is the $\alpha / \beta$ transformation (or the $\alpha / \beta$ phase field).

The effect of heating rate is demonstrated by a shift in the exothermic peak positions towards higher temperatures for increasing heating rates, as shown in Figure 2-(a). The higher the heating rate is, the higher the temperatures of the different peaks are. This is an effect observed in thermally activated reactions. Another more interesting effect of the heating rate is the amplitude variation of the different exothermic peaks between 350 and $600^{\circ} \mathrm{C}$ (area $\left.\mathrm{B}\right)$. At heating rates of 10 and $15^{\circ} \mathrm{C} / \mathrm{min}$, we clearly observe three different exothermic peaks 
whereas at the heating rate of $2^{\circ} \mathrm{C} / \mathrm{min}$, the peak 2 does not exist. This peak 2 is slightly visible at $5^{\circ} \mathrm{C} / \mathrm{min}$ but it is clearly less important in comparison to the two higher heating rates. The peak 1 is the main exothermic peak at the two lower heating rates but it seems to decrease at the expense of the peak 2 as the heating rate increases. This variation indicates a change in the exothermic mechanisms occurring in this temperature range which is linked to the heating rate. However, the relative amplitude of the peak 3 is not affected by the variations in heating rate. The large endothermic area labeled $\mathrm{C}$ on all the DSC curves corresponds to the $\alpha / \beta$ phase field. The T $\beta$ transus temperature is confirmed to be at about $860^{\circ} \mathrm{C}$. Additional DSC results on Ti-5553 and Ti-LCB have previously been reported by Carton et al. [16] with different starting microstructures, and they obtained different DSC curves.

\subsection{DSC Curves of Ti-LCB in the $\beta$-Solutionized State $\left(810^{\circ} \mathrm{C} / 30 \mathrm{~min} / \mathrm{WQ}\right)$}

DSC analyses carried out on $\beta$-solutionized Ti-LCB are shown on Figure 3. Two exothermic peaks are clearly illustrated at the four heating rates, the first between
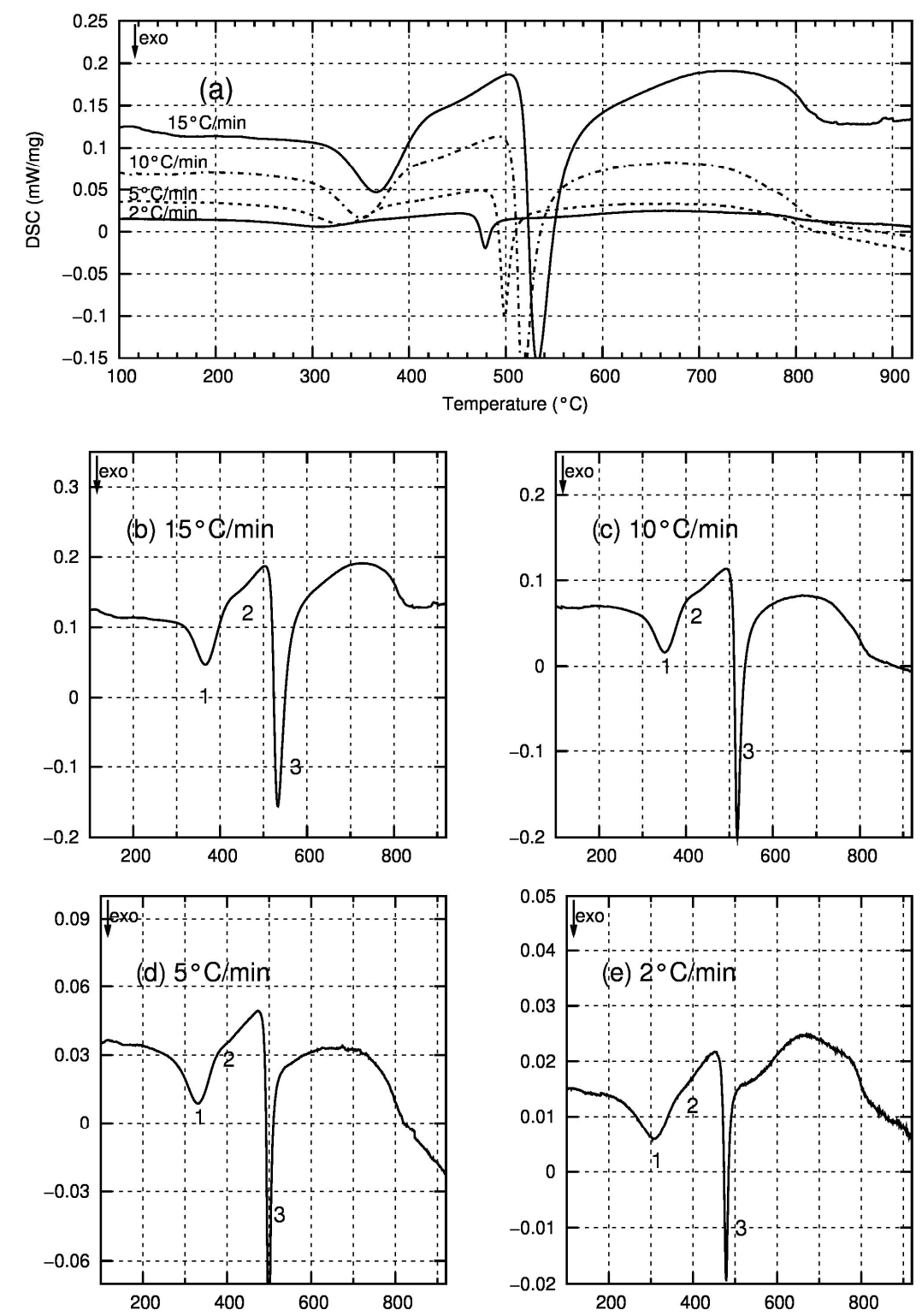

Figure 3. DSC curves of $\beta$-solutionized Ti-LCB $\left(810^{\circ} \mathrm{C}-30 \mathrm{~min} / \mathrm{WQ}\right)$ at: (a) the four heating rates; (b) $15^{\circ} \mathrm{C} / \mathrm{min}^{\circ}$ (c) $10^{\circ} \mathrm{C}$ $/ \mathrm{min}$; (d) $5^{\circ} \mathrm{C} / \mathrm{min} ;$ (e) $2^{\circ} \mathrm{C} / \mathrm{min}$. 
$300^{\circ} \mathrm{C}$ and $375^{\circ} \mathrm{C}$ (peak 1) and the second, the most important one, between $475^{\circ} \mathrm{C}$ and $550^{\circ} \mathrm{C}$ (peak 3). A less marked transformation seems to occur in the temperature range $400^{\circ} \mathrm{C}-450^{\circ} \mathrm{C}$, labeled peak 2 on the DSC curves. Heating rate influence is demonstrated through the shift in the peak position, but in comparison to the DSC curves of Ti-5553 in Figure 2, there is no variation in the relative intensity of the peaks. Heating rate in the range $2{ }^{\circ} \mathrm{C}-15^{\circ} \mathrm{C} / \mathrm{min}$ is not responsible for a significant modification of the DSC curves, and by extension we can assume that it does not influence the phase transformation mechanisms in the same way as in Ti-5553.

Prima [15] has studied in details the phase transformation in Ti-LCB. He carried out in situ resistivity measurements during continuous heating at $2^{\circ} \mathrm{C} / \mathrm{min}$. According to the variations observed on his resistivity curves, he divided the heating into four domains and made hypothesis correlated with experimental observations: domain I from room temperature to $200^{\circ} \mathrm{C}$ corresponds to the dissolution of $\omega_{\text {ath }}$, domain II from 200 to $350^{\circ} \mathrm{C}$ (peak 1 on Ti-LCB DSC) corresponds to the precipitation of $\omega_{\text {iso }}$, domain III from 350 to $480^{\circ} \mathrm{C}$ (peak 2 on Ti-LCB DSC) corresponds to the disappearance or coalescence of $\omega_{\text {iso }}$ and $\alpha$ precipitation, domain IV at $480^{\circ} \mathrm{C}$ (peak 3 on Ti-LCB DSC) corresponds to the formation of $\alpha$. Comparison between Prima's results and our DSC curves leads to the following correlation: peak

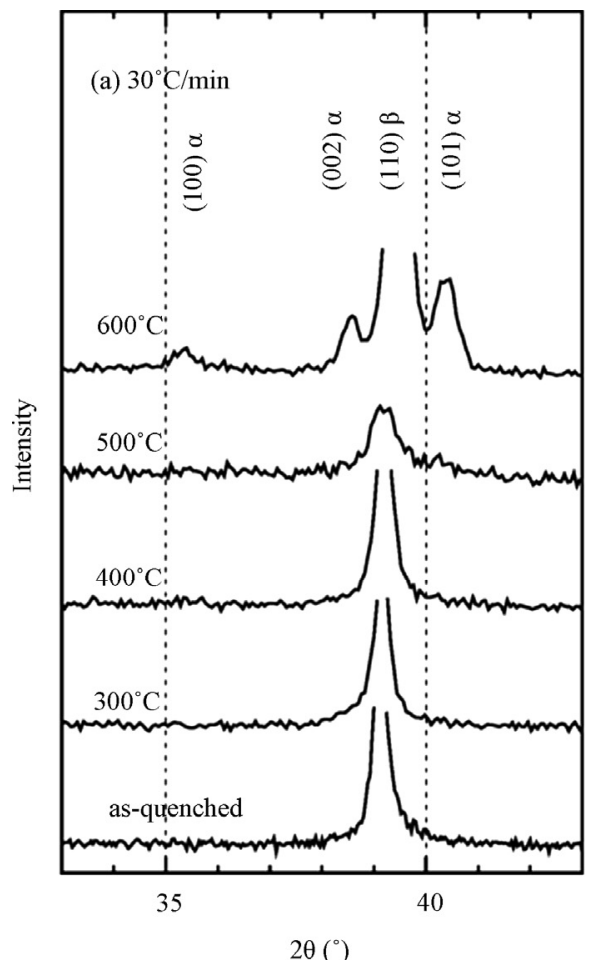

1 corresponds to the precipitation of $\omega_{\text {iso }}$ and peak 3 corresponds to the precipitation of $\alpha$ phase.

The comparison between Ti-LCB and Ti-5553, both $\beta$-metastable alloys, could lead us to think that peak 1 on the Ti-5553 DSC curves corresponds to $\omega_{\text {iso }}$ formation, peak 2 to the disappearance or coalescence of $\omega_{\text {iso }}$ plus $\alpha$ precipitation and peak 3 to the precipitation of $\alpha$ phase.

\subsection{Microstructure Analysis of $\beta$-Solutionized Ti-5553 After Heating to $300^{\circ} \mathrm{C}, 400^{\circ} \mathrm{C}$, $500^{\circ} \mathrm{C}$ and $600^{\circ} \mathrm{C}$ at Two Heating Rates of $2^{\circ} \mathrm{C}$ and $30^{\circ} \mathrm{C} / \mathrm{min}$.}

The $\beta$-solutionized Ti-5553 samples were heated at two different heating rates: $2^{\circ} \mathrm{C} / \mathrm{min}$ and $30^{\circ} \mathrm{C} / \mathrm{min}$ from room temperature to $300^{\circ} \mathrm{C}, 400^{\circ} \mathrm{C}, 500^{\circ} \mathrm{C}$ and $600^{\circ} \mathrm{C}$ followed by water quenching. According to the position of peaks on the Ti-5553 DSC curves (Figure 2), $300^{\circ} \mathrm{C}, 400^{\circ} \mathrm{C}$, $500^{\circ} \mathrm{C}$ and $600^{\circ} \mathrm{C}$ are approximately located between each exothermic DSC peak. As a consequence these temperatures are representative for the microstructural evolution displayed by DSC.

XRD investigations were carried out on each sample. Results are presented in Figure 4 in the range 20: $33-43^{\circ}$, where we find the main peaks of the $\alpha$ and $\beta$ phases. It is important to note that due to the small size of $\omega$ precipitates, they cannot generate characteristic peak on conventional

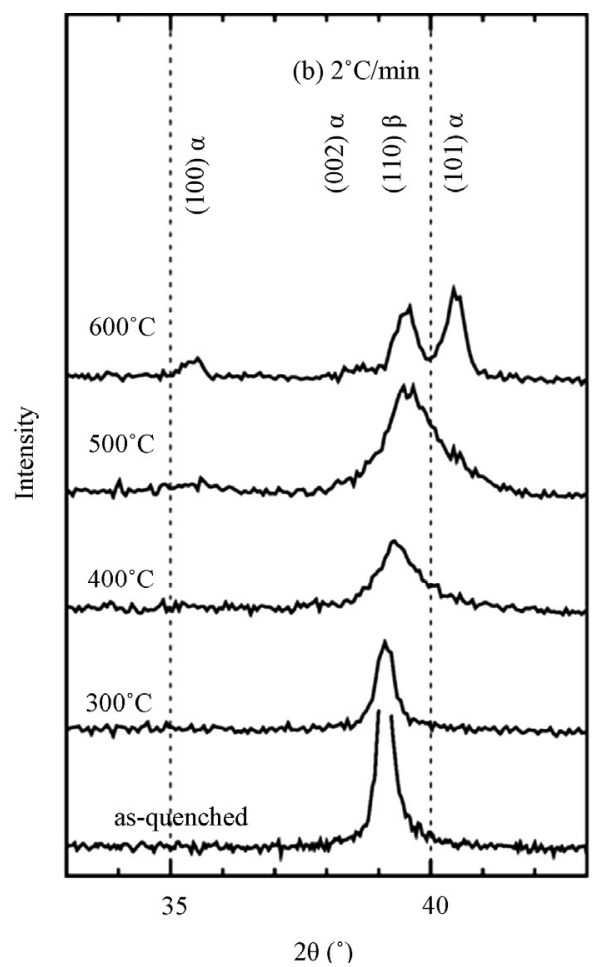

Figure 4. X-Ray diffraction data for $\beta$-solutionized Ti-5553 $\left(865^{\circ} \mathrm{C}-30 \mathrm{~min} / \mathrm{WQ}\right)$ after various heat treatments at two heating rates: (a). $30^{\circ} \mathrm{C} / \mathrm{min}$; (b). $2^{\circ} \mathrm{C} / \mathrm{min}$. 
XRD pattern as confirmed by Jones et al. [13]. In the $\beta$-solutionized state and after heating up to $300^{\circ} \mathrm{C}$, only the (110) $\beta$ peak is visible. After heating up to $400^{\circ} \mathrm{C}$ and $500^{\circ} \mathrm{C}$, we observe at the heating rate of $2^{\circ} \mathrm{C} / \mathrm{min}$ a widening and a shift of this peak to higher values of $2 \theta$. At the heating rate of $30^{\circ} \mathrm{C} / \mathrm{min}$, the widening of (110) $\beta$ is not observed at $400^{\circ} \mathrm{C}$ but it is observed at $500^{\circ} \mathrm{C}$. At both heating rates, after heating to $600^{\circ} \mathrm{C}$, characteristic peaks of the $\alpha$ phase appear whilst the $\beta$ peak is still visible. Between the $\beta$-solutionized state and the $600^{\circ} \mathrm{C}$ heating, the position of the (110) $\beta$ peak shift from $2 \theta=39.1^{\circ}$ to $2 \theta=39.6^{\circ}$.

At $2^{\circ} \mathrm{C} / \mathrm{min}$, XRD data show an evolution of the micro-

$30^{\circ} \mathrm{C} / \mathrm{min}$

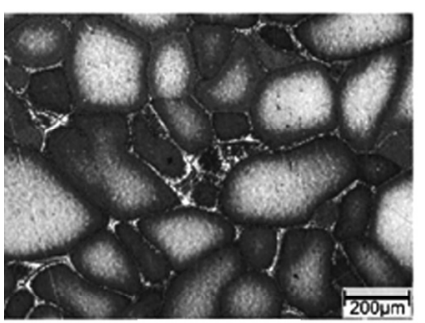

(a) $600^{\circ} \mathrm{C}$

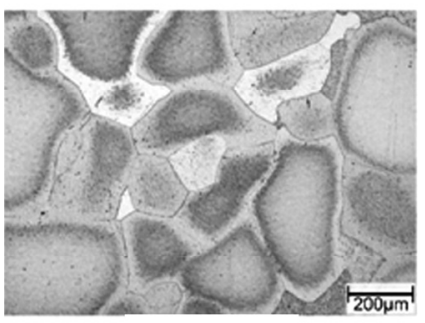

(b) $500^{\circ} \mathrm{C}$

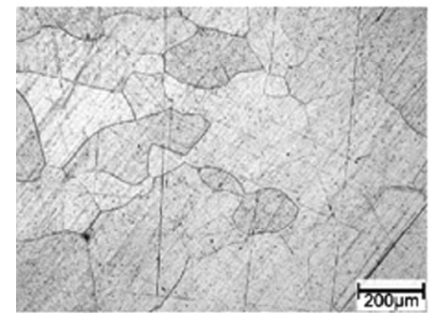

(c) $400^{\circ} \mathrm{C}$

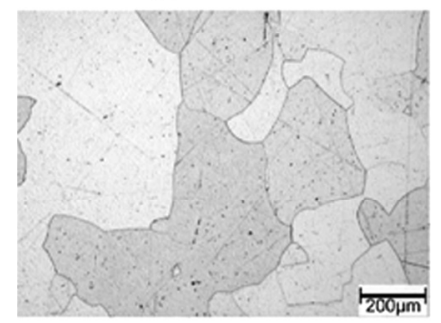

(d) $300^{\circ} \mathrm{C}$ structure between 300 and $500^{\circ} \mathrm{C}$. In this temperature range, no $\alpha$ phase is clearly detected as it is at $600^{\circ} \mathrm{C}$, so the widening of the (110) $\beta$ peak could correspond either to the precipitation of $\omega_{\text {iso }}$ or to the nucleation of very small $\alpha$ precipitates on the $\omega / \beta$ interface. Between 500 and $600^{\circ} \mathrm{C}$, XRD demonstrated the formation of the $\alpha$ phase.

The micrographs in Figure 5 evidence that heating Ti-5553 from a $\beta$-solutionized state up to $600^{\circ} \mathrm{C}$ at two different heating rates of 2 and $30^{\circ} \mathrm{C} / \mathrm{min}$ leads to different microstructures.

At the $2^{\circ} \mathrm{C} / \mathrm{min}$ heating rate, the response of the alloy heated up to $600^{\circ} \mathrm{C}$ to chemical etching consists of a

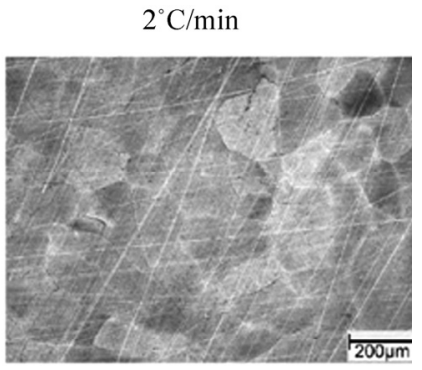

(e) $600^{\circ} \mathrm{C}$

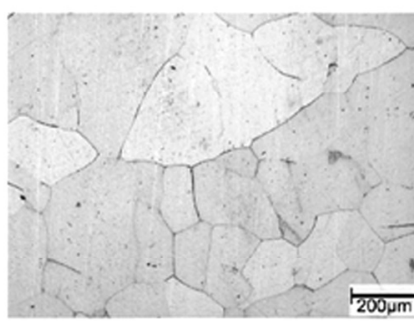

(f) $500^{\circ} \mathrm{C}$

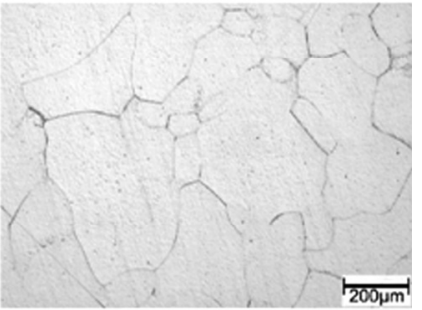

(g) $400^{\circ} \mathrm{C}$

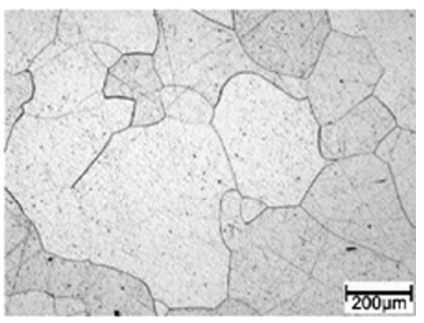

(h) $300^{\circ} \mathrm{C}$

Figure 5. LM micrographs of $\beta$-solutionized Ti-5553 $\left(865^{\circ} \mathrm{C}-30 \mathrm{~min} / \mathrm{WQ}\right)$ after various heat treatments at two heating rates: $(\mathrm{a}, \mathrm{b}, \mathrm{c}, \mathrm{d}) .30^{\circ} \mathrm{C} / \mathrm{min}$ and $(\mathrm{e}, \mathrm{f}, \mathrm{g}, \mathrm{h}) .2^{\circ} \mathrm{C} / \mathrm{min}$. Intragranular precipitation is observed on microstructures a) and b) whereas only microstructures a) exhibit grain boundaries precipitation. Chemical etching leads to a darkening of surface of sample e) due to $\alpha$ precipitation. 
complete darkening of the surface (Figure 5-(e)) making its observation by $\mathrm{LM}$ difficult. Between 300 and $500^{\circ} \mathrm{C}$, no change is observed by LM (Figure 5-(f) to (h)).

At the $30^{\circ} \mathrm{C} / \mathrm{min}$ heating rate, precipitation is not uniform, first precipitates appear inside the grains between 400 and $500^{\circ} \mathrm{C}$ (Figure 5-(b)) whereas larger precipitates appear at the grain boundaries between 500 and $600^{\circ} \mathrm{C}$ (Figure 5-(a)). The surface is darkened inside the grains whereas it is brighter at the grain boundaries. The precipitation occurring between 400 and $500^{\circ} \mathrm{C}$ inside the grains at $30^{\circ} \mathrm{C} / \mathrm{min}$ (Figure5-(b)) is not observed at $2^{\circ} \mathrm{C} /$ min (Figure 5-(f)).

SEM micrographs (Figure 6) confirm LM observations and reveal additional information. At $500^{\circ} \mathrm{C}$, at a heating rate of $30^{\circ} \mathrm{C} / \mathrm{min}$ (Figure 6-(c) and (d)), nanometer size intragranular precipitates can be observed at high magnifications whereas nothing appears at the grain boundaries. Between 500 and $600^{\circ} \mathrm{C}$, the $\alpha$ precipitates appear both inside the grains and at the grain boundaries
(Figure 6-(a) and (b)) but with different size. These precipitates are plate shaped and form "triangle" patterns that are fine inside the grain and coarser at the grain boundaries (Figure 6-(a)). These $\alpha$ precipitates observed at $600^{\circ} \mathrm{C}$ are termed "micron size $\alpha$ precipitates" in this paper and are defined as $\alpha_{\mathrm{M}}$ inside the matrix and $\alpha_{\mathrm{GB}}$ at grain boundaries. This difference in size of $\alpha$ precipitates between grain boundaries and rest the grain arises from the previous precipitation which takes place between 400 and $500^{\circ} \mathrm{C}$ inside grains and not at the grain boundaries. We do not know the exact chemical and crystallographic nature of these small precipitates because XRD data do not prove the presence of $\alpha$ phase. However the micrographies evidence that they are the precursors of the precipitation of $\alpha_{M}$ precipitates. Thus we choose to call these precipitates $\alpha_{\text {Mprec}}$.

At a heating rate of $2^{\circ} \mathrm{C} / \mathrm{min}$, no precipitates are visible at the quench temperature of $500^{\circ} \mathrm{C}$ (Figure 6-(h)) . The $\alpha$ phase precipitates homogeneously in the matrix

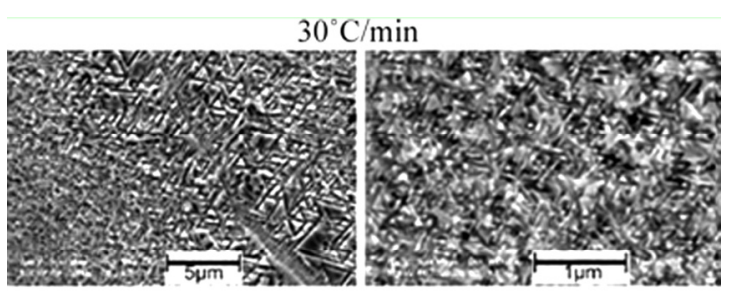

(a) $600^{\circ} \mathrm{C}-\mathrm{GB}$

(b) $600^{\circ} \mathrm{C}$ Intragranular
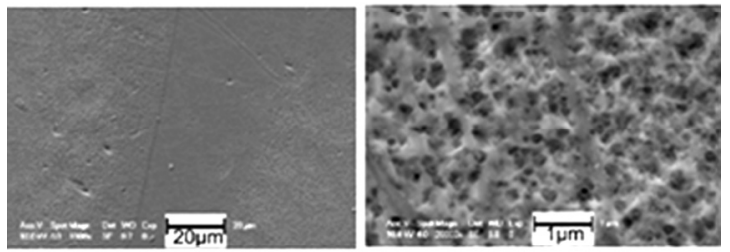

(c) $500^{\circ} \mathrm{C}-\mathrm{GB}$

(d) $500^{\circ} \mathrm{C}$ Intragranular
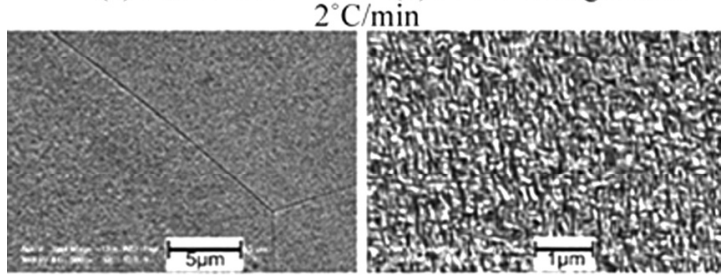

(e) $600^{\circ} \mathrm{C}-\mathrm{GB}$

(f) $600^{\circ} \mathrm{C}$ Intragranular
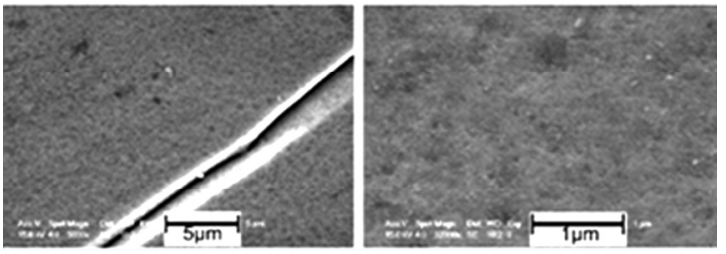

(g) $500^{\circ} \mathrm{C}-\mathrm{GB}$

(h) $500^{\circ} \mathrm{C}$ Intragranular

Figure 6. SEM micrographs of $\beta$-solutionized Ti-5553 $\left(865^{\circ} \mathrm{C}-30 \mathrm{~min} / \mathrm{WQ}\right)$ after heat treatments up to $500^{\circ} \mathrm{C}$ and $600^{\circ} \mathrm{C}$ at two heating rates: (a-d). $30^{\circ} \mathrm{C} / \mathrm{min}$ and $(\mathrm{e}-\mathrm{h}) .2^{\circ} \mathrm{C} / \mathrm{min}$. (GB $=$ grain boundaries). 
and at the grain boundaries between 500 and $600^{\circ} \mathrm{C}$, and resultant $\alpha$ plates are fine and homogeneously distributed (Figure 6-(e) and (f)). We did not observe any difference between the grain boundaries and the centre of grains. The arrangements of the precipitates are different from those observed at $30^{\circ} \mathrm{C} / \mathrm{min}$; they do not form triangle patterns but small plates.

Hardness variations with temperature are illustrated in Figure 7. Hardness indentations were sufficiently small to differentiate between intragranular and grain boundary hardness when differences were highlighted on the micrographs at $30^{\circ} \mathrm{C} / \mathrm{min}$. The comparison with XRD results (Figure 4) shows that increase of hardness is concomitant with the widening of the $\beta$ XRD peak. At a heating rate of $2^{\circ} \mathrm{C} / \mathrm{min}$, hardness increases between 300

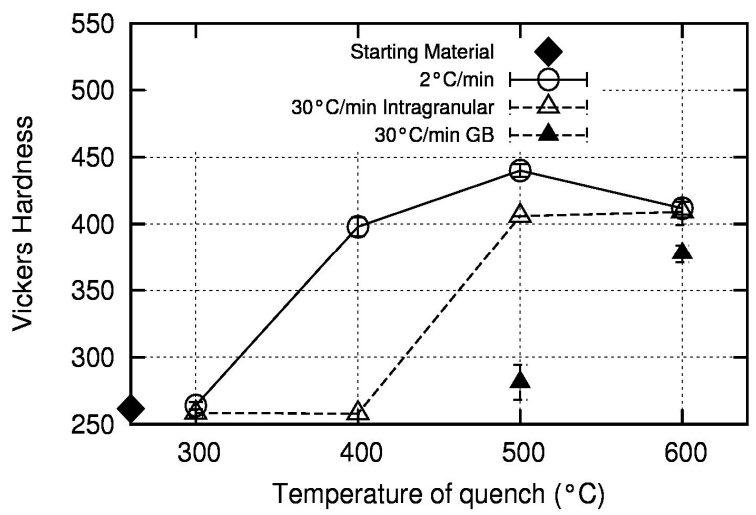

Figure 7. Vickers hardness of $\beta$-solutionized Ti-5553 $\left(865^{\circ} \mathrm{C}\right.$ $-30 \mathrm{~min} / \mathrm{WQ}$ ) after heating at two heating rates: $30^{\circ} \mathrm{C} / \mathrm{min}$ and $2^{\circ} \mathrm{C} / \mathrm{min}$. and $400^{\circ} \mathrm{C}$, maximum is reached at $500^{\circ} \mathrm{C}$ and slightly decreases with the appearance of micron size $\alpha$ precipitates at $600^{\circ} \mathrm{C}$. At a heating rate of $30^{\circ} \mathrm{C} / \mathrm{min}$, when no precipitation is observed, i.e. $300^{\circ} \mathrm{C}, 400^{\circ} \mathrm{C}$ and at grain boundaries at $500^{\circ} \mathrm{C}$, the hardness remains low; when precipitation is observed, the hardness increases, i.e. inside grains at $500^{\circ} \mathrm{C}$ and everywhere at $600^{\circ} \mathrm{C}$. The precipitation responsible for the increase in hardness at $30^{\circ} \mathrm{C} / \mathrm{min}$ is visible in LM after chemical etching whereas this is not the case at $2^{\circ} \mathrm{C} / \mathrm{min}$.

\section{Discussion}

A summary of the results is given in Table 2.

At $2^{\circ} \mathrm{C} / \mathrm{min}$ the DSC exothermic peak 1 is responsiblefor a widening of the $\beta$ XRD peak and an increase in hardness. According to experimental results from other authors $[9,11]$, this peak could correspond to the transformation of $\omega$ to nanometer size $\alpha$, this is not clear and it also could simply correspond to the formation of nanometer size $\omega_{\text {iso }}$. We assume the second hypothesis. Peak 3 corresponds unambiguously to the formation of micron size $\alpha$ precipitates. The homogeneous distribution of the micron size $\alpha$ indicates that $\omega_{\text {iso }}$ precipitates formed during heating are responsible for the increase in hardness and act as nucleation sites for the micron size $\alpha$ formation (DSC peak 3 ). The following $\beta$ phase decomposition is proposed:

$$
\beta+\omega_{\text {ath }} \rightarrow \beta \rightarrow \beta+\omega_{\text {iso }} \rightarrow \beta+\alpha
$$

At $30^{\circ} \mathrm{C} / \mathrm{min}$, DSC peak 1 is present but the difference with $2^{\circ} \mathrm{C} / \mathrm{min}$ arises from the appearance of DSC peak 2 . Peak 2 corresponds to the formation of intragranular

Table 2. Overview of all the experimental results at the two heating rates of $2^{\circ} \mathrm{C} / \mathrm{min}$ and $30^{\circ} \mathrm{C} / \mathrm{min}$.

\begin{tabular}{|c|c|c|c|c|c|c|}
\hline \multicolumn{2}{|c|}{ Heat treatment } & $\begin{array}{l}\text { Microstructure } \\
\text { at micron scale } \\
(\text { Figure } 5 \text { - 6) }\end{array}$ & $\begin{array}{c}\text { DSC } \\
\text { (Figure2) }\end{array}$ & $\begin{array}{c}\text { XRD } \\
\text { (Figure 4) }\end{array}$ & $\begin{array}{c}\text { Vickers } \\
\text { Hardness } \\
\text { (Figure 7) }\end{array}$ & $\begin{array}{l}\text { Supposed nanometer and micron } \\
\text { scale microstructure evolution }\end{array}$ \\
\hline \multirow{4}{*}{$\begin{array}{l}30^{\circ} \mathrm{C} \\
/ \mathrm{min}\end{array}$} & $600^{\circ} \mathrm{C}$ & $\begin{array}{l}\text { fine micron size } \alpha_{\text {Matrix }} \\
\text { and coarser micron size } \\
\qquad \alpha_{\mathrm{GB}}\end{array}$ & exothermic peak 3 & $\alpha+\beta$ peaks & $\begin{array}{c}409 \\
(\mathrm{~GB} 378)\end{array}$ & $\begin{array}{c}\text { fine precipitation of micron size } \\
\alpha_{\mathrm{M}} \text { inside grains nucleated on } \omega_{\text {iso }} \\
\text { and } \alpha_{\mathrm{Mprec}} \text { and coarser micron size } \\
\text { precipitation of } \alpha_{\mathrm{GB}} \text { at GB }\end{array}$ \\
\hline & $500^{\circ} \mathrm{C}$ & $\begin{array}{l}\text { fine intragranular } \\
\text { precipitation } \\
\text { and } P F Z \text { at GB }\end{array}$ & $\begin{array}{l}\text { exothermic peaks } 1 \text { and } \\
2\end{array}$ & $\begin{array}{l}\text { widening of } \beta \\
\text { peak }\end{array}$ & $\begin{array}{c}406 \\
(\mathrm{~GB} 281)\end{array}$ & $\begin{array}{l}\omega_{\text {iso }} \text { formation (peak } 1 \text { ) then for- } \\
\text { mation of } \alpha_{\text {Mprec }} \text { inside grains } \\
\text { (peak 2) but nothing at GB }\end{array}$ \\
\hline & $400^{\circ} \mathrm{C}$ & $\beta$ grains & $(\operatorname{area} \mathrm{A})$ & $\beta$ peak & 258 & dissolution of $\omega_{\text {ath }}$ \\
\hline & $300^{\circ} \mathrm{C}$ & $\beta$ grains & $(\operatorname{area} \mathrm{A})$ & $\beta$ peak & 258 & dissolution of $\omega_{\text {ath }}$ \\
\hline \multirow{4}{*}{$\begin{array}{l}2^{\circ} \mathrm{C} / \mathrm{m} \\
\text { in }\end{array}$} & $600^{\circ} \mathrm{C}$ & $\begin{array}{l}\text { fine micron size } \alpha \\
\text { precipitates }\end{array}$ & exothermic peak 3 & $\alpha+\beta$ peaks & 412 & $\begin{array}{c}\text { fine homogeneous precipitation of } \\
\alpha \text { nucleated on } \omega_{\text {iso }}\end{array}$ \\
\hline & $500^{\circ} \mathrm{C}$ & $\beta$ grains & exothermic peak $3 *$ & $\begin{array}{l}\text { widening of } \\
\beta \text { peak }\end{array}$ & 440 & $*$ \\
\hline & $400^{\circ} \mathrm{C}$ & $\beta$ grains & exothermic peak 1 & $\begin{array}{l}\text { widening of } \\
\beta \text { peak }\end{array}$ & 398 & $\omega_{\text {iso }}$ formation \\
\hline & $300^{\circ} \mathrm{C}$ & $\beta$ grains & $(\operatorname{area} \mathrm{A})$ & $\beta$ peak & 264 & dissolution of $\omega_{\text {ath }}$ \\
\hline
\end{tabular}

$\mathrm{PFZ}=$ Precipitate-free zone, $\mathrm{GB}=$ grain boundaries, $\mathrm{IntraG}=$ Intragranular

*According to the position of the $3^{\text {rd }}$ exothermic peak, micron size $\alpha$ should have been observed. 
nanometer size precipitates which are visible after chemical etching. Their exact nature is not known so we call them $\alpha_{\text {Mprec }}$. Peak 3 corresponds to the formation of micron size $\alpha$ precipitates, which are fine inside the grain $\left(\alpha_{\mathrm{M}}\right)$ and larger at the grain boundaries $\left(\alpha_{\mathrm{GB}}\right)$. Thus, two possible precursors exist at this heating rate: $\omega_{\text {iso }}$ and $\alpha_{\text {Mprec}}$, this lead to various mechanisms possible for the $\alpha$ phase precipitation and the following $\beta$ phase decomposition is proposed:

$\beta+\omega_{\text {ath }} \rightarrow \beta \rightarrow \beta+\omega_{\text {iso }} \rightarrow \beta+\alpha_{\text {Mprec }}+\omega_{\text {iso }} \rightarrow \beta+\alpha_{\mathrm{M}}+\alpha_{\mathrm{GB}}$

It is likely that the precipitation of $\omega_{\text {iso }}$ phase retards or prevents the precipitation of $\alpha_{\text {Mprec }}$. The $\omega_{\text {iso }}$ precipitation is sufficiently high at $2^{\circ} \mathrm{C} / \mathrm{min}$ to inhibit the formation of $\alpha_{\text {Mprec }}$ corresponding to DSC peak 2. At faster heating rates (e.g. 10,15 and $30^{\circ} \mathrm{C} / \mathrm{min}$ ) the exothermic peak 2 is present between 450 and $500^{\circ} \mathrm{C}$ so that the formation of the finely distributed intragranular precipitation of $\alpha_{\text {Mprec }}$ is not inhibited.

Our results clearly show that $\alpha$ nucleation in Ti- 5553 has different possible mechanisms depending on the heating rate. Clément [18], who studied Ti-5553, was confronted to the same difficulties in interpreting the responses of the different techniques he used to study phase transformations in Ti-5553. He found that differences in the peaks position may be observed with this alloy between various techniques so care should be taken with their interpretation.

Due to the nanometer size of the particles, precise responses could only be obtained with extensive and systematic TEM analyses or/and with in situ high energy XRD. This will be the subject of future studies, especially to verify if the $\alpha_{\text {Mprec }}$ precipitates could be an orthorhombic $\alpha$ " phase as proposed by Bruneseaux et al. for the $\beta$ phase decomposition of Ti17 [8].

\section{Conclusions}

The strong influence of heating rate in the range of $2-30^{\circ} \mathrm{C} / \mathrm{min}\left(=0.033-0.5^{\circ} \mathrm{C} / \mathrm{s}\right)$ on the $\beta$ phase decomposition of $\beta$-solutionized Ti-5553 was established using DSC analysis. Phase transformations were characterized by LM and SEM micrographs, XRD and hardness test. The results obtained are as follows.

1) Heating $\beta$-solutionized Ti-5553 up to $600^{\circ} \mathrm{C}$ at $2^{\circ} \mathrm{C} / \mathrm{min}$ of results in a fine and homogeneous distribution of $\alpha$ precipitates in the matrix. Formation of micron size $\alpha$ precipitates occurs between 500 and $600^{\circ} \mathrm{C}$. Before $300^{\circ} \mathrm{C}, \omega_{\text {ath }}$ disappear and $\omega_{\text {iso }}$ form between 300 and $400^{\circ} \mathrm{C}$. The $\omega_{\text {iso }}$ precipitates act as nucleation sites for $\alpha$ plates precipitation. Following sequence is proposed:

$$
\beta+\omega_{\text {ath }} \rightarrow \beta \rightarrow \beta+\omega_{\text {iso }} \rightarrow \beta+\alpha
$$

2) Heating $\beta$-solutionized Ti-5553 up to $600^{\circ} \mathrm{C}$ at $30^{\circ} \mathrm{C} / \mathrm{min}$ results in a fine intragranular distribution of micron size $\alpha_{M}$ precipitates and a coarser precipitation of micron size $\alpha_{\mathrm{GB}}$ at the grain boundaries. The formation of $\omega_{\text {iso }}$ is present between 350 and $450^{\circ} \mathrm{C}$ but not sufficiently to inhibit the formation of nanometer precipitates called $\alpha_{\text {Mprec }}$ which takes place between 450 and $500^{\circ} \mathrm{C}$. Both $\omega_{\text {iso }}$ and $\alpha_{\text {Mprec }}$ precipitates act as nucleation sites for $\alpha$ precipitation. Following sequence is proposed:

$$
\beta+\omega_{\text {ath }} \rightarrow \beta \rightarrow \beta+\omega_{\text {iso }} \rightarrow \beta+\alpha_{\text {Mprec }}+\omega_{\text {iso }} \rightarrow \beta+\alpha_{\mathrm{M}}+\alpha_{\mathrm{GB}}
$$

3) The precipitation of $\omega_{\text {iso }}$ phase retards or prevents the precipitation of $\alpha_{\mathrm{Mprec}}$.

4) Influence of slow heating rates on precipitation mechanisms cannot be generalized to all the $\beta$-metastable titanium alloys since Ti-LCB does not exhibit the same heating rate dependence on DSC curves.

With these experimental observations, it is shown that the $\omega$ precipitates have a strong influence in the $\beta$ to $\alpha$ phase transformation in Ti-5553 during a slow heating. Slow enough heating produces a fine and uniformly distributed $\alpha$ precipitation. In this precipitation sequence, the main factor is the time necessary to form a high enough volume of $\omega_{\text {iso }}$ precipitates. In an industrial process, the slow heating rate can reasonably be replaced by an isothermal treatment at $350^{\circ} \mathrm{C}$ followed by a heating to $600^{\circ} \mathrm{C}$ in order obtain a microstructure with a fine and homogeneous distribution of $\alpha$ plates. This technique could be used to design new microstructures in the $\beta$-metastable alloys.

\section{Acknowledgements}

The authors wish to thank the Walloon Region for funding and support.

\section{References}

[1] N. G. Jones, R. J. Dashwood, D. Dye and M. Jackson, "Thermomechanical Processing of Ti-5Al-5Mo-5V-3Cr," Material Sciences and Engineering: A, Vol. 490, 2008, pp. 369-377. doi:10.1016/j.msea.2008.01.055

[2] I. Weiss and S. L. Semiatin, "Thermomechanical Processing of Beta Titanium Alloys: An Overview," Material Sciences and Engineering: A, Vol. 243, 1998, pp. 46-65. doi:10.1016/S0921-5093(97)00783-1

[3] G. Lütjering, "Influence of Processing on Microstructure and Mechanical Properties of $(\alpha+\beta)$ Titanium Alloys," Material Sciences and Engineering: A, Vol. 243, 1998, pp. 32-45. doi:10.1016/S0921-5093(97)00778-8

[4] O. M. Ivasishin, P. E. Markovsky, S. L. Semiatin and C. H. Ward, "Aging Response of Coarse- and Fine-Grained $\beta$ Titanium Alloys," Material Sciences and Engineering: $A$, Vol. 405, 2005, pp. 196-305. doi:10.1016/j.msea.2005.06.027 
[5] O. M. Ivasishin, P. E. Markovsky, Yu. V. Matviychuk, S. L. Semiatin, C. H. Ward and S. Fox, "A Comparative Study of the Mechanical Properties of High-Strength $\beta$-Titanium Alloys," Journal of Alloys and Compounds, Vol. 457, 2008, pp. 296-309. doi:10.1016/i.jallcom.2007.03.070

[6] N. Wain, X. J. Hao, G. A. Ravi and X. Wu, "The Influence of Carbon on Precipitation of $\alpha$ in Ti-5Al-5Mo5V-3Cr," Material Sciences and Engineering: A, Vol. 527, 2010, pp. 7673-7683. doi:10.1016/i.msea.2010.08.032

[7] H. Chang, E. Aeby-Gautier, F. Bruneseaux and L. Zhou, "The Influence of Heating Rate on Phase Transformation Kinetics and Microstructures Evolutions at Ageing in MeTastable $\beta$ Titanium Alloy Ti-B19," In: M. Nimoni, S. Akiyama, M. Ikeda, M. Hagiwara, K. Maruyama, Eds., Ti-2007 Science And Technology, The Japan Institute, Vol. 2, 2007, pp. 973-976.

[8] F. Bruneseaux, G. Geandier, E. Gauthier, B. Appolaire, M. Dehmas and P. Boulet, "In Situ Characterization of the Transformation Sequences of Ti17 Alloy by High Energy X-ray Diffraction: Infkuence of the Thermal Path," In: M. Nimoni, S. Akiyama, M. Ikeda, M. Hagiwara, K. Maruyama, Eds., Ti-2007 Science and Technology, The Japan Institute, Vol. 1, 2007, pp. 563-566.

[9] Y. Ohmori, T. Ogo, K. Nakai, S. Kobayashi, "Effects of $\omega$-phase Precipitation on $\beta-->\alpha, \alpha$ " Transformations in a Metastable $\beta$ Titanium Alloy," Material Sciences and Engineering: A, Vol. 312, 2001, pp. 182-188. doi:10.1016/S0921-5093(00)01891-8

[10] F. Prima, P. Vernaut, G. Texier, D. Ansel and T. Gloriant, "Evidence of A-nanophase Heterogeneous Nucleation from $\Omega$ Particles in a $\beta$-metastable Ti-based Alloy by High-Resolution Electron Microscopy," Scripta Materialia, Vol. 54, 2006, pp. 645-648. doi:10.1016/j.scriptamat.2005.10.024
[11] N. G. Jones, R. J. Dashwood, D. Dye and M. Jackson, "Development of Chevron-shaped $\alpha$ Precipitates in Ti5Al- 5Mo-5V-3Cr," Scripta Materialia, Vol. 60, 2009, pp. 571-573. doi:10.1016/j.scriptamat.2008.12.010

[12] S. Nag, R. Banerjee, R. Srinivasan, J. Y. Hwang, M. Harper and H. L. Fraser, " $\omega$-Assisted Nucleation and Growth of $\alpha$ Precipitates in the Ti-5Al-5Mo-5V-3Cr-0.5Fe $\beta$ Titanium Alloy," Acta Materialia, Vol. 57, 2009, pp. 2136- 2147. doi:10.1016/j.actamat.2009.01.007

[13] N. G. Jones, R. J. Dashwood, M. Jackson and D. Dye, " $\beta$-Phase Decomposition in Ti-5Al-5Mo-5V-3Cr," Acta Materialia, Vol. 57, 2009, pp. 3830-3889. doi:10.1016/j.actamat.2009.04.031

[14] S. Azimzadeh and H. J. Rack, "Phase Transformations in Ti-6.8Mo-4.5Fe-1.5Al," Metallurgical Transaction: A, Vol. 29, 1998, pp. 2455-2467. doi:10.1007/s11661-998-0217-8

[15] F. Prima, "Etude Métallurgique D’un Nouvel Alliage de Titane $\beta$-métastable," PhD Thesis, INSA Rennes, France, 2000 .

[16] M. Carton, P. Jacques, N. Clément and J. LecomteBeckers, "Study of Transformations and Microstructural Modifications in Ti-LCB and Ti-555 Alloys Using Differential Scanning Calorimetry," In: M. Nimoni, S. Akiyama, M. Ikeda, M. Hagiwara, K. Maruyama, Eds., Ti-2007 Science and Technology, The Japan Institute, Vol. 1, 2007, pp. 491-494.

[17] A. Dehghan-Manshadi and R. J. Dippenaar, "Development of $\alpha$-Phase Morphologies During Low Temperature Isothermal Heat Treatment of a Ti-5Al-5Mo-5V-3Cr Alloy,' Material Sciences and Engineering: A, Vol. 528, 2011, pp. 1833-1839. doi:10.1016/j.msea.2010.09.061

[18] N. Clément, "Phase Transformations and Mechanical Properties of the Ti-5553 $\beta$-metastable Titanium Alloy," PhD Thesis, UCL, Belgium, 2010. 